\title{
The transformation of China's economic and government functions
}

\author{
ZHOU Yu-feng ${ }^{1,2}$ \\ (1. Department of Management, Chongqing Medical University, Chongqing 400016, China; \\ 2. Medicine and Social Development Research Center, Chongqing Medical University, Chongqing 400016, China)
}

\begin{abstract}
The content of China's economic transformation is not single, and this article argues that it includes three parts. The first is the reform of economic system, the second is the change in the pattern of economic growth, and the third is the adjustment of economic structure. Government is the leading force of China's economic transformation, and repeated reform of government institutions has brought about some changes to government functions. But problems are obvious that lag changes of government functions have become an obstacle in China's economic transformation. This article describes the historical evolution and the reality of China's economic transformation, and analyzes the main reasons of lag changes in government functions, and reveals that the transformation of government functions is the key for successful transformation of China's economy.
\end{abstract}

Key words: transformation; China’s economy; government functions

The content of China's economic transformation is not single, and it includes three parts. The first one is the reform of economic system, the second one is the change in the pattern of economic growth, and the third one is the adjustment of economic structure. Government is the leading force of China's economic transformation. The transformation of government functions is the key to economic transformation.

\section{The historical evolution and the reality of China's economic transformation}

\subsection{The historical evolution of China's economic transformation}

From 1949 to 2009, China has experienced two major economic transformations. One is the transition from the new democratic economy to a socialist planned economy, and the other is from a socialist planned economy to a socialist market economy. New democratic economy as a whole belongs to market economy, however, this kind of market economy has its own features-There are plans to regulate the market economy. In 1956, China successfully completed the socialist transformation of private ownerships, and at the same time, China also realized the necessity of transition from the new democratic economy to a pure planned economy. After the third plenary session of the eleventh central committee in 1978, China began to carry out an all-round reform and open up, and China's economic system has begun to gradually move from the socialist planned economy to a socialist market economy.

In 1979, comrade DENG Xiao-ping met with American visitors, and they talked about "the socialist system can also have a market economy". At that time, the concepts of commodity economy and market economy are still restricted in China. In 1981, China confirmed the existence of commodity production and commodity trading, but

ZHOU Yu-feng, associate professor of economics, Department of Management, Medicine and Social Development Research Center, Chongqing Medical University; research fields: economic theory and practice. 
didn't mention the concept of commodity economy. In 1982, China clearly put forward the view that planning tool is the main and market tool is complementary, but the concept of commodity economy is still difficult to be put forward. Until 1984, for the first time, China set forth that the socialist economy is the planned commodity economy based on the socialist public ownership. Comrade DENG Xiao-ping showed this point of view with new words that the ancestors have not said, and he wrote a new version of political economy. In 1987, China has clearly put forward the model of economic adjustment mechanism, which is the state controls market and market leads enterprises. In 1992, Comrade DENG Xiao-ping inspected the South of China, and delivered an important speech. He said: "More plan or more market is not the essential difference between socialism and capitalism”. Just in this year, China has clearly stated that the goal of China's economic reform is to establish a socialist market economic system.

\subsection{The reality of China's economic transformation}

After 30 years of reform and open up, the building of China's socialist market economy has made remarkable results: Market has played a fundamental role in the allocation of some important resources; Price, supply and demand, competition and so the market mechanism has taken shape; The primary stage of socialism basic economic system has been established; The legal status of non-public economy is confirmed; The common development of multi-ownership economy has basically taken shape in pattern; The social security system has been gradually established and further improved; The legal system of socialist market economy has begun to take shape; Government organs have been streamlined for many times and great changes have taken place in government functions.

In fact, China's economic transformation not only refers to the economic reform from planned economy to market economy, but also refers to the changes in the pattern of economic growth and the adjustment of economic structure. In 1995, China had put forward to achieve the fundamental transformation of economic growth. By 2005, China formulated the "eleventh five-year plan", and put forward that the focus work in the next five years is to realize the transformation of economic growth mode. In 2007, China stressed three changes of economic development model: From mainly relying on investment and exports change to relying on the coordinated development of consumption, investment and exports; from mainly relying on manufacturing industry change to relying on the coordinated development of the primary industry, manufacturing industry and tertiary industry; from mainly relying on resource consumption change to relying on the coordinated development of technological advances, improve the quality of workers and management innovation. In 2008, the subprime mortgage crisis erupted in the United States. The crisis has brought inevitable impact to China's economic, and China also found that some problems exist in the economic structure. China's economy in the past overly relied on exports and investment, but exports are greatly affected by the crisis. If China overly relied on investment to stimulate economic development, and it would inevitably cause the contradiction of overproduction and inefficient demand. So, although the Chinese government has paid a lot of effort for China's economic transformation, but the results were not good enough.

\section{Delay of China's economic transformation}

Six government structural reform was conducted since China's reform and opening up, and the purpose of government structural reform is to promote China's economic transformation, but there is a certain gap between the results and the expectation. 
In 1988, institutional reform proposed the proposition that transformation of government functions is the key to institutional reform for the first time. And China put forward such a view that the government's economic management should change from direct micro-management into indirect macro-management.

In 1993, institutional reforms were conducted by the backdrop of a socialist market economic system, and its core mandate is to establish the administration system adapted to the socialist market economic system.

In 1998, the principles of the State Council institutional reform are: In accordance with the requirements of the socialist market economy, changing government functions and separating government from enterprises; in accordance with the principle of simplification, uniformity and efficiency, adjusting government organizational structure; in accordance with the principle of unified rights and responsibilities, adjusting the responsibility and authority of the government, clear division of responsibilities among different departments.

In 2003, institutional reform was conducted by the backdrop of accession to the WTO, the focus of the institutional reforms is: deepening the reform of state-owned assets management system, improving macro-control system, perfecting the system of financial supervision and continuing to promoting the reform of circulation system.

In 2008, China began to carry out a new government structural reform which is called large sector institutions, and this reform highlights three main points: The first one is to strengthen and improve macro-control and to promote the development of science thinking; The second one is to ensure and improve people's lives, to strengthen the social management and public service; The third one is to adjust the departments of similar functions in accordance with the requirements of large sector institutions.

Although the previous structural reform has made some progress, in the end, there is a certain gap between results and expectations. This does not mean that the reform of government institutions for twenty years is nothing, or useless. The government ought to be the main driving force and leadership of China's economic transformation. In fact, it has become a major stumbling block of China's economic transformation.

(1) The factor of interests. In 1992, China put forward the direction of economic reform is to establish and perfect the socialist market economic system. The most basic requirement of market economy is that market must play a fundamental role in the allocation of resources, and the prices of resource should be largely determined by market supply and demand. However, in fact, Chinese government still holds the power of allocation for some important resources. The government officials were under the influence of utilitarian thinking for a long time, and hold the power of allocation for important resources. So, in fact, these important resources are not configured by the market, but by the government officials in accordance with their will. China's economic reform is far from finished, and the government will inevitably be subject to the temptation from a variety of external factors. In addition, in the process of government functions transforming, the government will adjust many interests. If this process does not receive effective supervision, the phenomenon of seeking private interest would appear in government departments.

(2) The factor of political achievement. Since the reform and open up, China has put forward the national policy that economic construction is the core of all. Therefore, many government agencies think that since economic construction is the center, GDP should mainly be used to measure the political achievement. Under the pressure of the performance evaluation, some local governments began to set up enterprises, attract investment and make construction project regardless of the actual. In order to obtain the growth of GDP, these local governments have not thought of other factors such as education, culture, health and environment. In addition, local governments have to carry out large-scale material production, or will not be able to maintain the balance of 
budgetary revenues and expenditures. These decisions and actions which were made by local governments have become obstacles to China's economic transformation.

(3) The factor of view. Government's self-positioning in the market economy is not accurate, and some local governments serve as the main body of the market economy naturally. Some government officials believe that they are the protagonists of the major decision-making and investment. Many government officials habitually think that their main achievement is to manage business and specific economic work well. These government officials did not realize such important view that the government's main duties in a market economy system are social services and macro-control. The government should provide good service to the people in education, health, housing, social security, etc. Thus, people could have plenty of consumer confidence, and the development of China's economy may have sustainability. This is a key component of China's economic transformation.

\section{The protection of China's economic transformation}

\subsection{Correct value is a prerequisite for successful economic transformation}

In the process of the government functions transformation, the government must have the correct value, which is a prerequisite for successful economic transformation. In the period of planned economy, China has no market, and the government has full responsibility for the management of enterprises. In the process of the establishment and improvement of market economic system, government must promote the building of market economy system, withdrawing from the field which should be regulated by the market itself, and government also should monitor the market order. In this process, the power of government will be increasingly smaller, and the influence of the market should be growing. However, in the process of economic transformation, if government's administrative power is too strong, it will not only hinder the normal development of the market, but also will breed a large number of corruptions. Therefore, the transformation of government functions is the protection of China's economic transformation. Wrong acts under the guidance of wrong values not only fail to promote economic transformation, but also have become an obstacle to economic transformation. In the socialist market economy, government is to serve the community, and must always put the social services as the government's top priority. Government should no longer be the main body in the allocation of resources, and the most important means of accessing to resources is the market but not the government. The Government's main function is to maintain a normal market order, rather than being responsible for the development of production. If the government personally engaged in business management, and achieved rapid economic growth, the government is still negligence, because the government's duty is not the specific management, but providing public services.

\subsection{Accurate position is the key to successful economic transformation}

In the process of the government functions transformation, the government must have accurate position, and this is the key to successful economic transformation. Firstly, the government did not do very well to provide public service. For an example, more and more students drop out of school. All this shows that the government is not well fulfilled the responsibility of education, health care, housing, social security, etc. The government should solve these problems and enhance consumer confidence, then achieve a smooth transformation of economic structure. Secondly, the government should not engage in specific economic work. The duty of the government is doing important decisions and macro-control. Thirdly, there are also some problems existing in the government's work such as environmental protection, social equity, etc. The government has not only created the miracle of rapid economic growth, but also paid a high price. Is the government only a night watchman? Government 
intervention in the economy is inevitable, but not omnipresent. In order to become an effective force in promoting economic transformation, the government must have accurate positioning.

\subsection{Help the people is the core of successful economic transformation}

In the process of the government functions transformation, the government must help the people, this is the core of successful economic transformation. China's economic transition means the change in the economic system first, in recent years, there has raised more refers to the change in the pattern of economic growth, and the most attention is the adjustment of economic structure after the subprime crisis. If the government functions neglected fundamental changes, the problem of insufficient domestic demand can not be fully resolved, too. This change will not be resolved by administrative means, but can be realized by the market mechanism. The government must pay attention to the structural problems of investment and consumption, combine the expansion of domestic demand and economic growth, and combine the expansion of domestic demand and the development of social undertakings, and combine the expansion of domestic demand and improvement of people's livelihood. China's current focus of the financial payment is medical, education, low-cost housing, environmental protection and other public undertakings. The core of China's economic transformation is to strengthen consumer confidence, and its essence is that the government must give the people actual benefit, effectively raise the real purchasing power of ordinary people. Only in this way, China's economic transformation would be successful, and China's economy could obtain a good long-term development.

\section{References:}

Chi Lo. (2008). Phantom of the china economic threat: Shadow of the next Asian crisis. New York: Palgrave Macmillan. Gregory C. Chow. (2007). China's economic transformation. Edinburgh: Blackwell Publishing Limited.

WEI Li-qun. (2009). Retrospect and prospect of China's thirty yers reform of economic system. Beijing: People's Publishing House. ZHAO Hui. (2008). Changing the governmental functions and building up a service government. Guangdong: People's Publishing House.

(Edited by Ruby and Chris)

(continued from Page 64)

References:

CHANG Xiu-ze. (2004). Transformation of economic growth mode under Chinese new development pattern. Theory Reference, 6, 13-16.

GUO Jin-long. (2000). International comparison of the transformation of economic growth mode. Beijing: China Development Press.

HU Zong-yi \& LI Feng. (2002). A study about the index system of evaluating the changes of economic growth pattern. Journal of Hunan University (Social Sciences), 16(1), 37-40.

JING Yue-jun (2004). Economic growth mode compared and enlighten from American and Japanese. Population Journal, 2.

LIU Shu-ru. (2006). Overall assessment research of economic growth quality in Shaanxi province. Xi'an: Northwest University Press.

LIU Shu-ru. (2004, August). The evaluating index system and the comprehensive evaluation of the changing way of economic increase in our country. Proceeding of 2004 International Conference on Management Science \& Engineering, 1457-1459.

XU Ying-mei \& DING Jun-jun. (2007). A new integrated method for selecting indices on evaluation of the macro-economy performance. Journal of Zhongnan University of Economics and Law, 4, 3-8.

(Edited by Ruby and Chris) 